\title{
3. Citizen media and civil resistance in West Papua
}

Abstract: This article charts the dynamics and trajectory of citizen media activism in West Papua's fight for freedom which has progressed from not even registering in news rooms around the world to influencing sub-regional and regional bodies. Citizen media has played an essential role in this transformation. In 1998, when the Indonesian military massacred more than 100 unarmed West Papuans in Biak Island, it took weeks and months to get the news out. Back then West Papua was a military operations area (Daerah Operasi Militer). Few journalists were willing to risk travelling into the country to get the story out. In January 2016 West Papua remains an occupied colony. The Indonesian government still tries to curtail open access to West Papua for foreign journalists but courageous young people armed with cell phones are finding ways to bypass the government's failed attempt at an informational blockade and it is making a difference. West Papuans are now members of the Melanesian Spearhead Group and the Pacific Island Forum is starting to take notice of the Pacific's longest running self-determination and decolonisation struggle.

Keywords: citizen media, conflict reporting, human rights, Indonesia, Melanesia, peace journalism, political journalism, West Papua

\section{JASON MACLEOD \\ University of Queensland}

N JULY 1998, Papuans gathered around the water tower in Biak City. For four days they sang hymns, prayed, danced, hoisted the Morning Star flag and demanded freedom. Protest leader Filep Karma stressed that he was engaged in a bold experiment (Karma, 2014; see also Karma, 2013):

I said that Papuans must fight peacefully.... I then told the people that my objective in raising the Morning Star flag at the Biak water tower was to tell the world that the Papuan nation desires to be free. [Before when Papuans raised] the flag in the jungle it was ineffective. Soldiers don't reach that area. No one sees it. But if you [raise the flag] in the town a lot of people can see it including the media and automatically the story gets disseminated globally. When I raised the Morning Star flag in Biak no one had ever done it. No one had kept the flag flying for 24 hours. When I did it in Biak I told my brothers and sisters who helped me, to keep it 
flying for more than 24 hours. Now we managed to do that. We kept the flag flying for four days.

In 1998 in Biak City, Karma and his compatriots were under the opinion that if they raised the Morning Star flag and kept it flying for at least 24 continuous hours then the United Nations would intervene and West Papua would become an independent state. West Papuans may not have had the most nuanced understanding of the vagaries of international politics but the Indonesian military were fully cognisant of the millenarian momentum behind Karma's movement (Kirksey, 2012). Indonesian politicians understood the power and value of symbols and rituals. Openly allowing expressions of Papuan sovereignty was not a view they were prepared to tolerate. In the days leading up to 6 July 1998 Indonesian troops had been gathering in Biak City. Three warships - at least one of which was sold to Indonesia by the then East Germany governmentand C-130 Hercules planes, the kind of aircraft the Australian government eagerly donated to Indonesia, brought in heavily armed troops-Hassanuddin Company from Sulawesi and Pattimura from Ambon, two neighbouring provinces. Local villagers from the surrounding hamlets were press ganged into militias and told to arm themselves with sharp implements. Captain Andrew Plunkett, a former intelligence officer who worked at the Australian Embassy in Jakarta, was quoted saying it 'was a dress rehearsal' for the militia-backed, military-led bloodletting and destruction that occurred post-referendum in East Timor in 1999 (Biak Tribunal, 2013).

Agus (2013), a West Papuan primary school student at the time, remembers what happened:

On the first day of the demonstration we heard people on the street. They were yelling 'Papua Merdeka'. At that time I did not understand what they were shouting about. We just followed the people to the tower. People were praying and singing. I saw a different flag flying from the top of the tower and I was really surprised. There were so many people and lots of police. The police saw us in our school uniforms. They told us to go back to school then they took us back to school. When the principal saw us he was angry. He said if anyone goes to the tower they will get a penalty.

On July 5 the headmaster closed the school but we had to stay because we were living at the school. The only other person at the school was a school security guard. No one went outside. No one went to the market. The headmaster and the teachers just told us to stay at school for our own safety. People everywhere were preparing to leave but we did not know what was happening....

The massacre was on a Monday. The night before-Sunday and the following morning - we heard everything. Our school is surrounded by a big fence. We couldn't see anything but we could hear what was happening. 
You need to know that a military police post and army complex is next to our school. So when the army moves we can hear everything. On the Sunday night we could hear heavy boots running beside the fence. Lots of boots. Running. We could not see but we could hear. We were so scared. We just sat there terrified, crying, listening to the sound of heavy boots running close to where we were. At that time we thought something would happen and we were really afraid. We just sat there hugging each other.

Around 4 am or 4.30 am on Monday, July 6, we heard gunshots. It was before dawn. We sat there in that room in the school hugging each other and crying. The shooting kept going. I was one of the youngest. The oldest was around 15. We did not know what to do except shed tears. All we could do was say, 'Oh God, what is happening?' The guns kept shooting until around $7 \mathrm{am}$.

When the shooting stopped my older brother came round to pick me up ... About two blocks from the Tower a woman ran up to the car begging for help. She was covered with blood. My brother quickly helped her get into the back of the car. When I turned around he told me not to look at her.

About a week later when I was back in East Biak I heard my parents tell of fishermen who were pulling up bodies in their nets....

After a month we went back to school. The headmaster forbids us to talk about what happened on that day. He said, 'Do not talk about the past.' He said that school could not be responsible for our safety. Two of our friends had disappeared. Their names are Johanes Orboy and Hermanus Fakdawer. They were both twelve years at the time. They were my friends but we never knew what happened to them and I did not dare ask. We just had to keep these things inside and leave them there.

A week later Edmund McWilliams, Political Counsellor at the US Embassy in Jakarta, arrived in Biak but it was many months before muted news of the massacre hit the foreign press (see Murdoch, 1998). McWilliams saw the bullet holes, chest high; pock marks over the water tower (McWilliams, 2013). It is not known how many died that day and in the days that followed. Some estimate over one hundred. Many Biak islanders who witnessed it say in excess of 150 people were killed that day and in the days that followed. No independent investigation has ever taken place. None of the mass graves dotted around Biak have been exhumed so the missing have not been accounted for and the dead have not been given a proper burial. Like other human rights atrocities such as the bloodletting after the 1965 coup, the Indonesian government refuses to even acknowledge what happened. The truth-just like the truth of what happened in so many other places in West Papua, such as Paniai in the mid-1960s, the Baliem Valley in 1977, Abepura in 2000, Wamena in 2000 and 2008, Waisor in 2001, Enarotali in 2014 - has been buried.

If protesters thought the killings would end with the shooting at the water 
tower they were mistaken. Much worse-unimaginable horror-was yet to come. Tieneke Rumkabu, who was caught up in the army attack when she took coffee to the protesters under the tower, testified to a quasi-legal citizens tribunal at Sydney University in 2013 about how she was imprisoned and tortured by police (Biak Tribunal, 2013).

They threw me onto a truck.... They took us to a place but we didn't know where. We were tortured with weapons - they make a cut on my hands and burn me with cigarettes. They cut with a sharp bayonet, then they pour acid. When I scream they burn me with cigarettes on both hands.... They brought candles and they burn the candles. They put it inside, into my vagina. I saw one of my friends, Martha, who was also tortured with the candles.... They put a bayonet in her neck and then in the vagina and also cut off her breasts and beheaded her... Then a man showed us a little knife, the one you use to shave, and he said 'we are going to use this to cut off your vaginas, from above and below, and from the left and from the right.' I saw a little girl, they raped her and then she died. All over the place it was blood everywhere because women's vaginas and clitorises had been cut out and they had been raped many, many times. They also hit another woman with a bayonet and then cut off the neck and also the breasts of the woman. Eight women were killed and they let four of us stay alive.... We didn't go home. I hide in the forest, the jungle, for two months.

When Tineke Rumkabu came out of the jungle she was arrested again and thrown in jail. The massacre may have occurred many years ago but the survivors are still being harassed. When I travelled to Biak in January 2015 I met with some of the survivors of that massacre. They had formed a support group, United for Truth (Bersatu untuk Kebenaran), and had begun advocating not just for themselves but for survivors of other human rights violations in West Papua as well. We had just fifteen minutes together before immigration and police intelligence raided the meeting. They did not want us to talk to the survivors.

According to ELSHAM (Institute for Human Rights Study and Advocacy in West Papua) and witnesses like Tineke Rumkabu, the dead and dying were dumped in trucks and taken to the wharf where they were loaded onto three waiting warships, KRI Kapap, KRI Telek Berau and one other. We know this from the pictures Dr Eben Kirksey, a US anthropologist, took from his hotel window at the time. Many of those still alive were then killed. The bodies were mutilated then thrown overboard. In the days following July 6 , corpses and many body parts washed up on the beaches of Biak. Irene Dimara, now a refugee living in Cairns, Australia, told me a fisherman found her brother, Dance Korwa: 'His penis had been cut off, he had no eyes, his teeth had been pulled out and he had more than five stab wounds in his belly' (Dimara, 2013). 
When news did start to trickle out about the massacre the Indonesian authorities could not hide all the bodies. Instead they claimed that the corpses were from the 17 July 1998 tsunami, the epicentre of which was off Aitape on the north coast of Papua New Guinea, more than 700 kilometres from Biak. However, the bodies that washed ashore did not wash up elsewhere in West Papua. One witness described a cadaver clothed in a Golkar shirt (an Indonesian political party). Another said the Morning Star flag could be seen, painted on the victim's chest.

Papuans call it Bloody Biak (Biak Berdarah), the 'Biak Massacre' in English and it was not the only mass killing that has taken place in West Papua. Many questions remain unanswered about it. Although human rights investigators from ELSHAM, the Institute for the Study and Advocacy of Human Rights in West Papua, visited Biak a week later and interviewed survivors and witnesses they were not able to conduct their work openly. Their detailed 69-page report, 'Graves without Names; Names without Graves' (ELSHAM, 1999) is the most comprehensive information we have but it remains, because of the circumstances - then and now-incomplete. Human Rights Watch (1998) also sent an undercover reporter but still there are substantial gaps. Further evidence, compiled during The Biak Massacre Citizens Tribunal that took place in Sydney fifteen years after the massacre, includes testimony from survivors, witnesses, journalists and investigators.

It is the Biak Massacre, its horror, the colluding silence in the domestic and international press; the complicity of Western powers who continue to train and arm the Indonesian military and police; the opportunistic avarice of the foreign corporations who exploit Papuan resources, giving nothing but crumbs in return; and the determination of Papuans to resist the occupation that sharpens Papuan resistance.

\section{Papuan Spring}

The fact that the post-Suharto state responded so decisively with the Biak Massacre was a rude awakening to those moderate West Papuan leaders who hoped that human rights violations and repression in West Papua would end with the demise of Suharto and his New Order.

After a series of discussions with high-ranking Indonesian politicians and bureaucrats, known as the Jakarta Informal Meetings, a team of 100 people (called Team 100) were invited to Jakarta for a special meeting with the then Indonesian President B J Habibie in February 1999. The purpose of the meeting was to discuss West Papuan grievances and a process of resolution. Prior to the meeting with Habibie, the West Papuan activists decided to limit discussion to problems related to development. However, emboldened by the knowledge that several members of the US Congress had sent a letter to Habibie and his most powerful opponent, Amien Rais, calling for dialogue on the political status of 
East Timor and West Papua, several political leaders involved with Team 100 privately began to re-evaluate their objectives to include full independence.

When Team 100 met with Habibie, a number of West Papuans launched into an impassioned plea for independence. Stunned and clearly misinformed about the depth and extent of discontent in West Papua, Habibie put aside his prepared response and in an emotional appeal urged the West Papuan delegation to reconsider their desire to separate from Indonesia. Although there was no clear outcome from the meeting, the West Papuan struggle had exploded onto Indonesia's political centre stage. West Papuans' long-suppressed desire for independence was now on the table and Team 100 returned home to a hero's welcome.

After returning from the meeting with Habibie a number of prominent West Papuan political leaders immediately began preparations for a national consultation called Musyuwarah Besar, often shortened to Mubes, on the causes of conflict in West Papua and strategies to achieve merdeka (freedom and independence). Mubes, which was held in February 2000, attracted thousands of West Papuans from all around the country. It was a bold act of political defiance. The long-banned Morning Star flag flew free and the desire for independence was expressed openly. Delegates held elections to form the PDP, the Presidium Dewan Papua or Papuan Presidium Council, a kind of parallel government made up of a 31-member executive (the Presidium) and a 500-member panel of local representatives from every region of West Papua (the Council). The PDP then agreed to hold a congress six months later-the Second Papuan Congress, taking its name from the 1961 national congress that formed the West New Guinea Raad, the parliament established by the Dutch.

The Second Papuan Congress, held between May 29 and 4 June 2000 in Port Numbay/Jayapura, was attended by West Papuan leaders living in exile and representatives from every sector of society and region in West Papua. Outside the meeting tens of thousands of West Papuans who could not fit into the overflowing auditorium danced and held vigil, applying moral pressure on even the most moderate West Papuan leader to support independence. Based on photographs from the time and interviews with participants and witnesses, including the handful of foreigners, I estimate around 50,000 West Papuans were in attendance.

The PDP targeted the Achilles' heel of Indonesia's occupation, directly challenging Indonesia's legitimacy to rule West Papua. They rejected both the 1962 New York Agreement and the sham UN-sponsored Act of Free Choice and declared that West Papua was already independent and was currently being illegally occupied by the Indonesian state. In a communiqué released at the conclusion of Mubes, Theys Eluay, PDP chair and his deputy, Thom Beanal, issued the following statement: 
We condemn outright the illegal transfer of sovereignty of the Papuan people from the Kingdom of the Netherlands to the Republic of Indonesia via the United Nations [that] concluded on 1st of May 1963. The transfer is deemed illegal as we, the very people directly affected by the decision, have never been consulted nor given any opportunity to have any say whatsoever through our national legislature, The Papuan National Council, the mandated body in existence at the time that should have ultimately been responsible for determining the political destiny of the Papuan people.

The Presidium's goal was a third party-mediated dialogue on the political status of West Papua. Unfortunately for the PDP, the space for dialogue with Jakarta had clearly closed after the meeting with Habibie. There was no longer a credible nonviolent movement in West Papua that could compel Jakarta to sit at the table. Moreover, in the wake of 'losing' East Timor, renewed nationalist vigour in Indonesia functioned to harden the Indonesian government's position. The chance of dialogue with Jakarta, when the opening bid was independence, was clearly non-existent.

However, the formation of the PDP also acted as a catalyst for third party support, dramatically raising the profile of the struggle, leading to renewed grassroots movement building work in Europe, North America, Australia, Aotearoa/ New Zealand and to a lesser extent the Pacific. In the face of a persistent and disciplined nonviolent movement and growing international support that exposed human rights violations by the Indonesian state and questioned Jakarta's legitimacy in West Papua, the Indonesian government, eager to maintain its newfound reformist image, found it increasingly difficult to justify repression and military operations in the way that it had been able to do in the past.

The Indonesian state's strategy to reassert its control in West Papua, after losing ground to the PDP, was made clear in a leaked letter entitled 'Rencana Operasi Pengkondisian Wilayah dan Pembangunan Jaringan Kommunikasi dalam Menyikapi arah Politik Irian Jaya untuk Merdeka dan Melepaskan Diri dari Negri Kesatuan Republik Indonesia' ('Operational Plan for Changing Conditions in the Territory and the Establishment of a Communications Network in Dealing with the Direction of Political Developments in Irian Jaya in Favour of Independence and Demanding Separatism from Indonesia'). The letter outlined a carrot-and-stick approach that included decapitating the West Papuan leadership, military operations to eradicate separatism, establishing pro-Indonesian militias, and improving social welfare.

\section{Collapse of Special Autonomy and return to repression}

The carrot to complement the Indonesian government's stick was first Special Autonomy, then administrative division, pemekaran, a policy ironically translated as 'expansion' and sometimes as ‘flourishing'. On paper Special Autonomy was a far- 
reaching proposal that sincerely attempted to address core West Papuan grievances within the framework of a united Indonesian state. However, its promise has not been realised. Despite a substantial redirection of revenue from mining, oil and gas, proceeds that formerly went to Jakarta and are now returned back to the provincial government in West Papua, health and income levels have actually deteriorated under Special Autonomy. As the pro-democracy activists in other parts of Indonesia worked to institutionalise the 1998 reform agenda, in West Papua human rights violations, including torture, increased (Hernawan 2013).

Even as Special Autonomy was instituted, Jakarta's iron fist fell. Efforts to keep the Morning Star flag flying in Wamena were brutally repressed in October 2000. Then on 10 November 2001, the flamboyant chair of the PDP, Theys Eluay, was strangled to death by soldiers from Kopassus (Komando Pasukan Khusus or Indonesian Special Forces Command) after attending a dinner party as the military's guest of honour. And while individual members of the PDP continue to be politically active, the jailing of PDP leaders, followed by the assassination of Theys Eluay, was a blow from which the PDP never recovered.

The military also renewed military operations, particularly in the Highland areas. One such operation in 2005 left over 6000 internally displaced people barely eking out an existence in the mountains and jungles and hundreds of homes, schools, churches, and health clinics burned to the ground (Wing and King, 2005). Another military operation in December 2006 resulted in similar numbers of internally displaced people being too scared to return to their homes. In addition, a network of militias was established. By 2000, reports started circulating that Laskar Jihad, a Muslim militia group, had established itself in West Papua and begun a programme of training and recruitment. In the Highlands, the militia group BMP (Barisan Merah Putih or Red and White Garrison) was formed. In Timika, Eurico Gutteres - the notorious East Timorese militia leader out on bail for his part in the post-referendum violence that was organised and perpetrated by the TNI and their militia proxies in East Timor-formed the Red and White Defenders Front.

It was clear that by 2001 the brief Papuan Spring that burst into flower so dramatically in 1998 had come to an end.

\section{The movement for dialogue and Papua as a land of peace}

Despite localised movement successes, including two dramatic strikes at the giant US-Anglo Freeport gold and copper mine and the important learning about organisation and resistance that came with them, the larger picture remained grim. The Indonesian military was quickly reasserting its control over the territory. Religious leaders were concerned that the formation of militias like Laskar Jihad could ignite the kind of inter-communal violence between diverse ethnic and religious communities that had occurred in Central Sulawesi 
and Maluku. In this context the idea of Papua as a Land of Peace with its goal of peaceful dialogue began to take shape. The Papua Land of Peace campaign created a dilemma for the military. Would the military speak out against the campaign and risk signalling their resistance to peace in Papua as well as alienating one of the most respected constituencies in Papuan society, religious leaders; or would they support the concept of Papua being a Land of Peace and thereby undermine their ability to ferment militia activities? Although TNI military commanders in Papua emphasised that there was no need for the campaign because there was already peace in Papua, the campaign most likely played an important role in constraining more covert militia operations. By mid to late 2000, reports of militia activity virtually ceased and by late 2002 Laskar Jihad was officially disbanded. While rumours of other Muslim and nationalist militias continued, their activities were low level, confined to training and meetings, and never reached the peak of the early 2000s. On the side of the pro-independence movement there were changes as well. Papuan guerrillas stood down and for several years publicly committed to giving space for peaceful dialogue to work.

However, the opportunity for peace talks was squandered. Jakarta rebuffed overtures by political and religious leaders in West Papua and simply refused to talk unless the question of West Papua's political status and future was taken off the agenda. In the meantime, direct violence, economic exploitation and marginalisation, alienation from traditional lands, cultural dislocation, plus a steady stream of mass migration from other parts of Indonesia combined with institutional racism was giving rise to a discourse of 'slow motion genocide'. Papuan activists across the political spectrum from religious to resistance leaders still talked about the desire for political dialogue with Jakarta. But they were no longer talking about Papua as a Land of Peace. Instead they used the phrase 'Papua, Zone of Emergency' (Papua Zona Darurat). By 2008/9 the Papua Land of Peace campaign was essentially over.

\section{Non-cooperation spreads to state institutions}

Special Autonomy was also losing the little lustre it had. The newly formed Council of Customary Chiefs, the Dewan Adat Papua, organised a large mobilisation of 10,000 to 15,000 people to march with a coffin marked 'Otsus'the Indonesian language contraction for Special, Khusus, and Autonomy, Otonomi - through the streets of Jayapura to the Provincial Parliament Building. While the demonstration laid the symbol of the death of Otsus at the door of the Provincial Parliament, the protesters's demands were mainly centred on external targets. The international community was a key focus.

Mass demonstrations against Special Autonomy resumed again in 2010. This time the protest was led by members of the Majelis Rakyat Papua (Papuan People's Assembly), a kind of indigenous senate, assisted by youth leaders 
and a small group of strategically savvy elders. On June 18, several thousand demonstrators (reports vary from between 2000 to 15,000) from seven districts converged on the provincial parliament in Jayapura to officially hand over the people's decision. Protest leaders gave members of the DPRP until July 8 to hand back Otsus. That time expired with no indication from the DPRP that they would even publicly discuss the issue. So on the morning of July 8 demonstrators mobilised outside the MRP building in Kotaraja and began a long march into the DPRP building in Jayapura (approximately 10 kilometres away). Accounts of exact numbers vary. The International Crisis Group and police reported 2500 to 3000 demonstrators but several photos and eyewitness accounts obtained by me indicate that the number was in excess of 10,000, and possibly as high as 25,000. Mass based organisations like DAP, the West Papua National Committee and the West Papua National Authority helped mobilise their members and reported to West Papua Media, an external based independent media outlet, in real time to coordinate international media.

When members of the DPRP failed to receive them - the Speaker of the House, John Ibo, was away in Jakarta—5000 demonstrators decided to occupy the parliament overnight. Simultaneous demonstrations were organised in Timika, Manokwari, Merauke and Wamena. Privately a small block of a dozen parliamentarians supported the protesters's demands but, caught between the government in Jakarta who demanded loyalty to the state and their constituents who were clamouring for a referendum, the group felt too scared to say anything publicly. By $5 \mathrm{pm}$ on Friday July 9, nearly 36 hours after the Papuans occupied parliament, police were getting ready to forcibly remove the demonstrators.

The decision by protesters to peacefully disperse was made a few hours later. When it was given, everybody - a few thousand people representing a range of different groups and with different ethnic affiliations-all left the parliament grounds. This nonviolent discipline in itself was remarkable. Contrast this to when protesters threw stones in 2006, ultimately killing five members of the Indonesian security apparatus. Back then the police reacted with deadly violence. As a result of the killing of the Indonesian officers, any moral high ground the protesters might have had evaporated. This time - in July 2010 - there was a clear organising structure and discipline was maintained, which kept the emphasis on the message, the failure of Otsus, rather than on protester behaviour. And although the action was high risk, no one was killed.

The protesters did not succeed in achieving their most immediate objectivea special session of parliament to debate the failure of Otsus - but they did learn a lot about organising and the power of unity.

\section{Independence declared-again}

The occupation of parliament failed to result in a third-party-mediated dialogue, 
or a referendum. Nor did it precipitate discussion about Special Autonomy. Faced with intransigence on the part of the Indonesian government, Papuan leaders escalated tactics, calling for another mass public meeting, the Third Papuan People's Congress, to debate the struggle. On 19 October 2011, the last day of the Congress - a three-day gathering of unarmed resistance groupsPapuan leaders formed the NFRWP (National Federal Republic of West Papua) and declared independence, again. The response from the security forces was swift and brutal. About an hour after the congress concluded, the Indonesian security forces opened fire. Three Papuans were shot dead. Two were fatally stabbed. Three hundred people were arrested and beaten. Six of the leaders were jailed, charged with treason. The police-who shot, stabbed, beat and tortured people - received warning letters.

The killing of protesters at the congress - relayed by mobile phone, Facebook, YouTube and mailing lists—outraged Papuans and their supporters outside the country. The arrest, beating and killing of protesters even divided political elites inside Indonesia. It attracted more third-party support for the West Papuan cause and revealed the extent to which the Indonesian state would go to deny Papuan aspirations for freedom.

The occupation of the provincial parliament in June 2010 and the Indonesian security forces's fatal attack on unarmed Papuans at the Third Congress in October 2011 was also evidence that the social media revolution had well and truly arrived in West Papua. In July 1998, when the Indonesian military opened fire on activists under the water tower in Biak, it took weeks and months for the news to get out. Even now we still do not have a comprehensive forensic account of what happened. By October 2011 the news was instantaneous, even though no international journalists were present. (I do not think I will ever forget the frightened voices of Papuan friends who called me from the grounds of the Catholic Seminary where the Third Congress was held. In the background I could hear the sound of gunshots.)

By 2013 social media was influencing the opinion of heads of state. At the MSG (Melanesian Spearhead Group), an important sub-regional forum with links to both the Pacific Island Forum and the United Nations, Gordon Lilo, former Prime Minister of the Solomon Islands, said that social media was highlighting human rights violations in West Papua, calling the situation a 'cyber war' with Indonesia and likened social media posts to 'cyber bullets' (Dorney 2013). In February 2015, Peter O’Neill, Prime Minister of Papua New Guinea, was even more forthright (Garrett, 2015). In an extraordinary speech he embraced West Papuans as 'our people':

I think as a country the time has come for us to speak about the oppression of our people. Pictures of the brutality of our people appear daily on 
social media and yet we take no notice. We have a moral obligation to speak for those who are not allowed to talk. We must be the eyes for those who are blindfolded. Again, Papua New Guinea, as a regional leader, must lead these discussions with our friends in a mature and engaging manner.

Then, on 10 May 2015, Indonesian President Joko Widowo issued a surprise announcement: foreign journalists would be free to visit West Papua. Unfortunately, Jokowi's statement was not backed up by a Presidential Decree or any other legal mechanism that might give the 'new' policy certainty. Less than 24 hours after Jokowi's statement the Minister for Security and Political Affairs, Tedjo Edhy Purdijatno, told the Indonesian media that the nothing had changed, journalists would still need permission from various government agencies. That permission involves navigating an 'interagency clearance house supervised by the Ministry of Foreign Affairs and involving 18 working units from 12 different ministries, including the National Police and the State Intelligence Agency' (Human Rights Watch, 2015, pp. 1-2). This can take months for many journalists and often ends in rejection. Indonesian military commander General Moeldoko confirmed Purdijanto's statement separately, saying that the previous rules remained. Papuan police also announced that foreign journalists would still be required to report to them and that their activities would be monitored. As long as the Indonesian government values propaganda over a free press, the battle for open access to West Papua will be ongoing. The Surat Jalan system, the architecture through which the police and intelligence services try to monitor foreign visitors, remains in place.

Denying access is hurting the Indonesian government's reputation. Besides, social media is making it impossible to enforce. The challenge for the movement is to use citizen media activism more effectively, to extensively cover the geographic expanse of Papua, to record and disseminate accurate data, and to upskill the movement more systematically, in order to promote and direct moral outrage.

\section{Resurgence of the diplomatic struggle}

On the diplomatic level Papuans also continue to organise employing both human rights mechanisms through the UN Human Rights Council and political mechanisms through international forums. There is also ongoing exploration of the possibilities of legal challenges to Indonesian sovereignty. In addition, Papuan churches are renewing their links with the Pacific Conference of Churches. In a game-changing intervention, the Vanuatu government, Council of Churches and the Malvatumauri National Council of Chiefs, brought together West Papuan leaders to Port Vila in November 2014 to reconcile and unify (MacLeod, 2015). Assisted by a team from the Pacific Conference of Churches the West Papuans agreed to form the United Liberation Movement for West Papua (ULMWP), an 
umbrella group that united the three largest coalitions of resistance groups inside the country. Perhaps the most visible sign that the struggle has become internationalised occurred at the Melanesian Spearhead Group meeting in Honiara in June 2015 when the ULMWP were accepted as observers (MacLeod 2015). A vibrant social media, sticker and poster campaign 'Bring West Papua Back to the Family' was widely taken up by solidarity groups in Papua New Guinea, Fiji, the Solomon Islands and Vanuatu. When West Papuan leaders travelled to Honiara one of the first things they did was establish relationships with journalists from the two dailies, The Solomon Star and the Island Sun, assisted by the local solidarity group 'Solomon Islands for West Papua'. The ULMWP also organised their own press secretary, the eminently capable Joey Tau, who helped place 140 separate stories in the Solomon Star and the Island Sun plus additional stories in other media outlets across the Pacific. In private and public, MSG leaders were clear: their people demanded that Melanesian leaders accept West Papua as members. After the MSG the ULMWP then went on to successfully push the Pacific Island Forum to call for a human rights fact-finding mission.

\section{Conclusion}

Since 1998, nonviolent means for addressing Papuan grievances and pursuing Papuan aspirations have been used more regularly and more extensively than violence or conventional political activity. In July 1998 Papuans kept the flag flying, hoping it would herald independence. Local media were too scared to report the story and foreign media were completely unaware it was happening. Seventeen years later, in 2015, the movement has matured into a co-ordinated international force, committed to a strategy of nonviolent resistance and diplomacy with citizen media at its heart. The struggle has gone from international obscurity to an important agenda item at sub-regional and regional forums.

Although at the time of writing, the formation of the ULMWP is still recent, it remains, in my view, the most significant event in the history of Papuan resistance. Eschewing brittle hierarchical forms of organisation, the ULMWP has established a decentralised network structure with visible leadership based outside the country and a hidden collective leadership structure inside the country. To date the secretariat seems to be negotiating this complex inside/outside arrangement with mature agility. As a result of this visible unity and coordination provided by the five-member executive, the ULMWP is attracting broad-based support from allies across the Pacific.

Merdeka ('freedom') may still be a distant dream, but it is one that is more alive than ever before. 


\section{References}

Agus (2013). Interview with the author, July 5.

Biak Tribunal (2013). Retrieved from www.biak-tribunal.org

Dimara (2013), interview with the author, July 5.

Dorney, S. (2013). Conflicting views on West Papua bid to join MSG. ABC News, retrieved from www.abc.net/australiannetwork/focus/s3792784.htm.

ELSHAM (1999). Graves without names; names without graves. Cited at www.biaktribunal.org.

Garrett, J. (2015). PNG Prime Minister wants to do more for Melanesians in West Papua. ABC PM on 5 February. Retrieved at www.abc.net/pm/content/2015/s4174912.htm.

Human Rights Watch (2015). Something to hide? Indonesia's restrictions on media freedom and rights monitoring in Papua. November. New York, NY: Human Rights Watch

Human Rights Watch (1998). Indonesia human rights and pro-independence actions in Irian Jaya. 10(8). December. New York, NY: Human Rights Watch.

Karma, F. (2013). The Biak Massacre Citizens Tribunal, July 6 [Video testimony]. Retrieved at www.biak-tribunal.org.

Karma, F. (2014). Seakan kitorang setengah binatang: Rasialisme Indonesia di Tanah Papua, Jayapuira: Deiyai,

Kirksey, E. (2012). Freedom in entangled worlds: West Papua and the architecture of global power. Durham: Duke University Press.

MacLeod, J. (2015a). Merdeka and the Morning Star: Civil resistance in West Papua. Brisbane: University of Queensland Press.

MacLeod, J. (2015b). A new hopeful chapter in West Papua's 50-year freedom struggle. Waging Nonviolence Retrieved from http://wagingnonviolence.org/feature/newhopeful-chapter-west-papuas-50-year-freedom-struggle-begins/.

McWilliams, E. (2013). Edmund McWilliams Testimony: Recalling the 1998 massacre in Biak. The Biak Massacre Citizens Tribunal, July 6. Retrieved from www.biaktribunal.org/edmund-mcwilliams-testimony-recalling-the-1998-massacre-in-biak.

Murdoch, L. (1998, November 17). Irian Jaya massacre: Church team to investigate Biak killings. Sydney Morning Herald.

Wing, J., and King, P. (2005). Genocide in West Papua? The role of the Indonesian state apparatus and a current needs assessment of the Papuan people. Sydney: West Papua Project, CPACS, University of Sydney.

Dr Jason MacLeod is a lecturer in community development in the School of Social Work and Human Services at the University of Queensland, an academic adviser for the International Centre for Nonviolent Conflict, and a research fellow with the West Papua Project at the Centre for Peace and Conflict Studies at the University of Sydney. He is the author of Merdeka and the Morning Star: Civil resistance in West Papua (2015, University of Queensland Press), reviewed on p. 241. This article is an edited extract by the author.

j.macleod@uq.edu.au 